\title{
SOSIALISASI PEMBENTUKAN KEMANDIRIAN DAN KEPERCAYAAN DIRI PESERTA DIDIK PAUD BINA ANANDA KABUPATEN LAHAT
}

\author{
Ariyanti Agus $\mathbf{P}^{1}$, Alfitri ${ }^{2}$, Didi Tahyudin ${ }^{3}$ \\ ${ }^{1,2,3}$ Program Studi Magister Sosiologi \\ Fakultas Ilmu Sosial dan Ilmu Politik Universitas Sriwijaya Palembang \\ Alamat e-mail: ${ }^{1}$ ariyantiaguspratiwi14@gmail.com
}

\begin{abstract}
Abstrak
Potret membangun karakter yang terabaikan saat ini memperlihatkan kualitas hasil pendidikan anak usia dini (PAUD) belum signifikan, oleh karena itu penting untuk memperbaiki pendidikan karakter di lingkungan PAUD melalui kegiatan pembelajaran edukatif. Penelitian ini bertujuan untuk menggambarkan proses sosialisasi pembentukan kemandirian dan kepercayaan diri peserta didik dan menganalisis hambatan yang terjadi selama proses sosialsiasi serta strategi untuk mengatasi hambatan di PAUD. Hasil penelitian diperoleh bahwa preparatory sebagai tahap penentu peserta didik mengikuti play stage dengan menjadikan guru sebagai role model melalui aktivitas yang membentuk kesadaran diri. Secara keseluruhan hasil terlihat pada game stage dan generalized stage melalui interaksi dilingkungan sosial. Dari proses sosialisasi diperoleh hambatan berupa kemampuan anak yang kurang maksimal di preparatory, adanya keterbatasan fasilitas dan kompetensi guru PAUD. Sehingga strategi yang digunakan dengan mengoptimalkan kemampuan anak, pemenuhan fasilitas dan peningkatan kompetensi guru.
\end{abstract}

Kata Kunci: sosialisasi; kemandirian; kepercayaan diri;

\begin{abstract}
The portrait of building the current neglected character shows the quality of early childhood education (PAUD) results is not significant yet, therefore it is important to improve character education in PAUD through educational learning activities. This study aims to describe the socialization process of pupils' self-reliance and selfconfidence establishment and analyze the obstacles occuring during the socialization process, and strategies to overcome obstacles in PAUD. The results show that preparatory is a determining stage for pupils to take part in play stage by making teachers as role models through activities shaping self-awareness. The overall results are seen in the game stage and generalized stage through social environment interactions. In the socialization process, the obstacles of pupils' abilities that are not optimal are found in preparatory, because of limited facilities and competencies of PAUD teachers. So, the strategy used is to optimize pupils' abilities, fulfill the facilities and increase teachers' competencies.
\end{abstract}

Keywords: self-reliance; self-confidence; socialization;

\section{PENDAHULUAN}

Pelaksanaan pembangunan karakter bangsa (nation and character building) menjadi salah satu fokus terpenting di dalam dunia pendidikan Indonesia melalui character education. Pendidikan karakter (character education) dipandang sebagai penentu cita-cita pembangunan bangsa menjadi besar, maju, bermartabat dan 
mencegah terjadinya krisis moral generasi muda (Samani dan Haryanto, 2017). Hakikatnya untuk membentuk seorang individu menjadi manusia ideal yang baik secara moral dan pribadi yang kuat, secara konsepnya berdasarkan pada sembilan karakter dasar, meliputi cinta kepada allah, tanggung jawab, disiplin, dan mandiri, jujur, hormat dan santun, kasih sayang, peduli, dan kerja sama, percaya diri, kreatif, kerja keras, dan pantang menyerah, keadilan dan kepemimpinan, baik dan rendah hati, toleransi, cinta damai dan persatuan. (Kurniasih dan Sani, 2017)

Tahapan pendidikan karakter juga harus didukung berdasarkan pada 11 prinsip Character Education Quality Standards (Majid dan Andayani, 2017) yang berfokus pada pembangunan karakter bangsa terutama untuk anak usia dini periode golden age usia 0 sampai 6 tahun. Hal ini dilakukan sebagai upaya memperbaiki situasi yang ada dengan membangun karakter pada generasi muda Indonesia sejak usia dini. Pendidikan karakter memiliki peranan penting dalam memperbaiki karakter dan melakukan penguatan melalui proses pembelajaran menggunakan sosialisasi di lingkungan pendidikan yaitu rumah (orangtua), pemerintah, sekolah (guru) dan masyarakat.

Alasan terpenting untuk memfokuskan pendidikan karakter pada anak usia dini melalui PAUD di Indonesia dikarenakan hasilnya masih belum terlihat signifikan. Hal tersebut terlihat pada kualitas anak yang kurang kritis, kurang mandiri, cenderung pasif, kurang kreatif, kurang berani, sehingga anak kurang memiliki kepercayaan diri yang mengakibatkan kurang maksimalnya kemampuan dalam melakukan interaksi sosial dengan lingkungan (Wiyani dan Barnawi, 2017). Menurut Soedarsono (2009) berdasarkan pada tabel potret membangun karakter untuk pembentukan di usia dini masih terabaikan yaitu di lingkungan rumah pengasuhan dan pengawasan yang banyak diserahkan pada pembantu, dilingkungan sekolah masih dipertanyakan dan dalam lingkungan masyarakat masih kurang kondusif dalam pemenuhan lingkungan layak anak (dalam Samani dan Haryanto, 2017).

Hal diatas menjadi penyebab kurangnya pendidikan ideal yang harus diterima anak diusia awal dalam lingkungan keluarga. Keluarga seharusnya menjadi lingkungan pendidikan pertama untuk belajar anak melalui interaksi. 
Rozana, dkk (2017) menyatakan bahwa orangtua memegang kunci utama dan memiliki peranan terpenting untuk bertanggungjawab mengawasi terhadap proses pembentukan karakter anak. Lingkungan sekolah dan masyarakat harus mendukung keberlanjutan proses membangun karakter. Robert Dreeben (dalam Sunarto, 2004) menjabarkan bahwa selain di dalam lingkungan keluarga proses sosialisasi pada anak juga berlangsung dalam lingkup pendidikan (sekolah). Dalam proses tersebut tidak hanya berfokus pada kegiatan membaca, menulis, dan berhitung, tetapi memfokuskan pada aturan dalam kemandirian, prestasi, universalisme, dan spesifisitas. Untuk dilingkungan sekolah proses sosialisasi anak diarahkan untuk harus belajar menjadi mandiri dan bertanggung jawab menyelesaikan semua kegiatan yang dilakukan. Hal ini dikarenakan pendidikan (sekolah) mempersiapkan serta membentuk anak agar dapat melakukan penguasaan terhadap peran-peran baru dan tidak akan memiliki ketergantungan terhadap orang lain terutama orangtuanya.

Pembentukan karakter kemandirian dan kepercayaan diri pada diri anak merupakan salah satu modal yang harus dimiliki oleh setiap individu. Tanggungjawab serta kedisiplinan dalam diri seorang individu akan berdampak pada pengelolaan perilaku serta keterampilan melalui kedisiplinan dalam lingkungan sosial. Dalam pandangan Masrun dan Martaniah (1986) menyatakan bahwa kemandirian belajar pada peserta didik didukung oleh kebebasan, progresif, inisiatif, kemampuan dalam pengendalian diri. Melalui proses kemandirian belajar, secara tidak langsung dari sikap, pola pikir, perilaku peserta didik akan meningkatkan keyakinan dan kepercayaan pada diri.

Kemandirian diri anak yang dibentuk dari interaksi guru dan anak dalam proses perkembangan sosial terjadi melalui komunikasi dan sosialisasi selama kegiatan belajar. Proses interaksi guru dan anak melalui komunikasi selama kegiatan belajar sambil bermain di kelas, dengan mengajak anak berbicara selama bermain. Kemandirian pada diri anak akan dilihat pada kemampuan anak dalam mengambil pilihan atau keputusan dengan menggunakan pikirannya sendiri dan menyertakan konsekuensi yang diterima (Mustofa, 2008). Secara konsep Zimmerman (1998) menyatakan bahwa ciri-ciri anak yang memiliki kepercayaan 
diri merupakan kunci utama untuk membentuk kemandirian pada anak, sehingga anak akan mampu untuk berkembang dengan cepat dan tepat. Apabila anak memiliki kemandirian, maka anak juga akan memiliki kepercayaan diri dan motivasi diri untuk meminimalisir bantuan orang lain (dalam Koro, dkk 2017).

Dariyo (2011) menjelaskan bahwa apabila anak memiliki kepercayaan diri yang membuat dirinya mempunyai kemampuan sebagai seorang individu yang memahami dan menyakini bahwa dirinya memiliki seluruh kemampuan dalam melakukan penyesuaian diri secara intensif, kreatif dan optimis terhadap apa yang dipilihnya. Lingkungan pendidikan pengembangan karakter pada peserta didik dilakukan guru melalui proses pembelajaran dengan memberikan contoh yang positif. Proses dimana peserta didik berada pada tahapan persiapan dengan memperhatikan dan meniru apa yang diajarkan oleh guru pendamping. Untuk hasilnya anak mulai mampu bertindak atau melaksanakan sendiri sebagai suatu kebiasaan tanpa harus di berikan perintah.

Secara keseluruhan akan terlihat pada proses penerimaan norma kolektif nantinya anak sudah memiliki kesiapan mental dalam dirinya dan mampu untuk menyesuaikan diri dengan lingkungan yang lebih besar. Menurut Samani dan Hariyanto (2017) upaya yang secara sadar dan maksimal oleh guru dalam menanamkan nilai positif pada anak, hasilnya akan menjadi suatpu kebiasaan dalam berpikir, berbuat, bersikap peduli, sehingga akan selalu berlandaskan pada nilai etik kepada diri sendiri maupun orang lain.

Pelaksanaan pendidikan karakter yang dilakukan oleh guru pendamping harus mampu mempelajari setiap karakteristik peserta didik, agar mampu memberikan pendidikan yang tepat dan tidak memaksakan. Kegiatan yang selalu dilakukan secara berulang-ulang merupakan bagian dari upaya dalam membangun karakter pada anak. Proses pembelajaran yang dilakukan akan membantu perkembangan anak secara cepat dan tepat (Lickona, 2013). Dalam perkembangan dan pertumbuhan anak usia dini berdasarkan pada sembilan karakter dasar yang akan sangat menentukan pembentukan nilai karakter dan kepribadian pada anak Kurniasih dan Sani (2017). Penjabaran Lickona (2013) mengenai pendampingan yang dilakukan oleh guru dalam lingkup kecil di kelas, dengan memperlakukan 
peserta didik yang memiliki dua hubungan antara guru dan anak. Tentunya akan berpotensi untuk memberikan pengaruh positif atau negatif terhadap perkembangan karakter seorang anak.

Karakter kemandirian dan kepercayaan diri pada anak usia dini merupakan karakter yang tepat untuk ditanamkan. Hal ini dikarenakan anak berada di fase untuk mengeksplor semua kegiatan dan anak memiliki rasa ingin tahu terhadap hal baru. Fase selanjutnya akan berkembang pada fase imitasi, dimana anak akan meniru semua apa yang dilihatnya dan anak akan menyimpan dalam memorinya mengenai apa yang terjadi disekitarnya. Dalam fase ini anak akan sangat peka mengenai semua yang terjadi, sehingga lingkungan yang baik akan sangat memberikan pengaruh positif bagi pembentukan karakter pada diri anak. Idi (2014:7-9) munculnya kerjasama antara pendidik dan anak didik di dalam proses kegiatan yang berlangsung di kelas, dalam perspektif sosiologi pendidikan merupakan suatu kegiatan yang termasuk pada penggunakan prinsip sosiologis meliputi metode, organisasi sekolah, evaluasi pembelajaran dan pelaksanaan kegiatannya.

Menggunakan konsep diri pada pemikiran Mead dalam teori interaksionisme simbolik (dalam Ritzer, 2012) untuk menggambarkan proses sosialisasi kemandirian dan kepercayaan diri peserta didik PAUD Bina Ananda Kabupaten Lahat adalah dimulai dari tahap persiapan, meniru, siap bertindak, dan penerimaan norma kolektif. Berdasarkan data yang diperoleh dari PAUD Bina Ananda Kabupaten Lahat diketahui bahwa data tersebut menunjukkan 57 persen siswa cenderung memiliki kemandirian dan kepercayaan diri yang rendah. Hasil ini diperoleh dari peserta didik yang mengikuti kegiatan belajar tahun ajaran 2018/2019 rata-rata dikategorikan pada kemandirian dan kepercayaan diri dengan bantuan oranglain yaitu guru pendamping PAUD.

Merujuk pada data di atas, PAUD Bina Ananda harusnya dapat menghasilkan siswa yang memiliki kemandirian dan kepercayaan diri, mengingat salah satu tujuan dari PAUD berbentuk kelompok bermain tersebut untuk membentuk anak menjadi pribadi yang mandiri dan percaya diri di usia dini. Akan tetapi fakta di lapangan menunjukkan bahwa siswa pada PAUD tersebut masih 
dikategorikan memiliki kemandirian dan kepercayan diri yang cenderung rendah, sehingga peneliti melihat perlunya untuk dilakukan kajian ilmiah terkait sosialisasi pembentukan kemandirian dan kepercayaan diri pada peserta didik di PAUD Bina Ananda Kabupaten Lahat.

Berdasarkan uraian yang telah dijabarkan dalam latar belakang, maka yang menjadi rumusan masalah dalam penelitian ini adalah "Bagaimana pelaksanaan sosialisasi pembentukan kemandirian dan kepercayaan diri peserta didik PAUD Bina Ananda Kabupaten Lahat?". Adapun untuk menjawab masalah utama yang menjadi pertanyaan penelitian sebagai berikut; 1) Bagaimana proses sosialisasi pembentukan kemandirian dan kepercayaan diri peserta didik PAUD Bina Ananda Kabupaten Lahat?, 2) Apa saja hambatan dalam proses sosialisasi pembentukan kemandirian dan kepercayaan diri peserta didik?, 3) Bagaimana strategi dalam mengatasi hambatan proses sosialisasi pembentukan kemandirian dan kepercayaan diri peserta didik?

\section{METODE}

Penelitian ini menggunakan metode deskriptif kualitatif dan dilakukan di PAUD Bina Ananda Kabupaten Lahat. Metode penelitian deskriptif kualitatif yaitu dengan menggali informasi dan menyampaikan fakta yang menjelaskan tentang proses sosialisasi pembentukan kemandirian dan kepercayaan diri peserta didik PAUD. Hasil penelitian yang diperoleh dari data primer dan data sekunder. Data primer berdasarkan pada penemuan fakta di lapangan meupakan tahapan menemukan data untuk mengetahui bagaimana proses sosialisasi pembentukan kemandirian dan kepercayaan diri peserta didik yang dilakukan dengan observasi pada lokasi penelitian dan wawancara langsung dengan Informan penelitian berjumlah 11 orang terdiri dari informan penelitian yaitu 4 orang peserta didik sebagai unit analisis, 2 orang informan kunci yaitu guru pendamping, 1 orang kepala sekolah dan 4 orang orangtua peserta didik yang dijadikan sebagai informan pendukung. Untuk data sekunder penelitian diperoleh dari dokumen PAUD Bina Ananda, literatur, studi pustaka, jurnal dan artikel berkaitan dengan penelitian. 
Penelitian ini membahas proses sosialisasi dengan menggunakan strategi etnometodologi yang merupakan strategi penelitian untuk mengkaji bagaimana manusia membangun dan memberi makna untuk setiap tindakan dalam situasi sosial konkret, seperti dalam kehidupan sehari-hari (Denzin dan Lincoln, 2009). Penggunaan strategi penelitian etnometodologi, dikarenakan dalam penelitian ini dengan berusaha menarasikan mengenai setiap interaksi yang terjalin antara semua unsur yang mendukung dalam proses sosialiasi pembentukan kemandirian dan kepercayaan diri peserta didik PAUD Bina Ananda Kabupaten Lahat.

\section{HASIL DAN PEMBAHASAN}

Untuk menganalisis sosialisasi pembentukan kemandirian dan kepercayaan diri peserta didik PAUD Bina Ananda Kabupaten Lahat, maka digunakan konsep sosialisasi dari Mead (dalam Ritzer, 2012). Sosialisasi merupakan suatu proses belajar seseorang berdasarkan proses yang terdiri dari preparatory, play stage, game stage dan generalized stage. Proses belajar memerlukan bimbingan dari pelaku sosialisasi yaitu orangtua, pendidik dan masyarakat dengan menyusun sistem-sistem psikofisik (kebiasaan) melalui kegiatan pembelajaran edukatif.

Proses sosialisasi yang bertujuan membentuk karakter diri dari peserta didik, berkaitan dengan penyesuaian diri ketika mengikuti kegiatan belajar yang berlangsung dalam lingkungan sekolah. Hal ini dikarenakan sekolah mengarahkan peserta didik untuk harus belajar mandiri, bertanggung jawab dengan meminimalisir ketergantungan terhadap orang lain, dan menjadi kunci utama terbentuknya kepercayaan diri.

\section{Proses Sosialisasi Pembentukan Kemandirian dan Kepercayaan Diri Peserta Didik}

Prepararoty peserta didik memfokuskan pada proses adaptasi dan pengembangan diri melalui aktivitas sehari-hari yang dilakukan setiap pagi dengan menyisipkan nilai-nilai positif dalam kegiatan interaksi secara verbal guru dan peserta didik. Proses pengenalan terhadap lingkungan sosial baru, orang dewasa baru yaitu guru pendamping PAUD, kawan sebaya, dan kegiatan baru yang 
sebelumnya tidak maksimal dilakukan oleh pendidikan informal (keluarga). Persiapan diri peserta didik dimulai dengan pengenalan terhadap lingkungan baru melalui aktivitas yang dilakukan oleh komponen utama yaitu guru pendamping. Aktivitas yang selalu diperoleh anak disetiap pagi hari secara terus menerus dilakukan dalam faktanya dilapangan memberikan nilai positif bagi anak untuk meniru. Kegiatan preparatory yang dilakukan peserta didik yaitu dimulai dengan anak diantarkan ke PAUD sampai kedepan kelas oleh orangtua dan bertemu dengan guru untuk diajak mencium tangan orang tua dan guru ketika sampai. Setelah itu anak diajak memasuki ruangan kelas, tetapi sebe;um memasuki ruangan kelas, anak diminta untuk melepaskan sepatu dan meletakkan di lantai kelas/ tempat yang disediakan. Anak juga diminta untuk masuk kelas dengan meletakkan tas ditempat duduk masing-masing. Kegiatan selanjutnya peserta didik diajak untuk membaca doa, yang dilanjutkan dengan kegiatan I yaitu bernyanyi. Adaptasi selanjutnya melalui kegiatan bermain edukatif oleh peserta didik dengan kawan-kawan sebaya untuk melatih komunikasi secara verbal dan bersosialisasi terhadap lingkungan yang akan lebih luas.

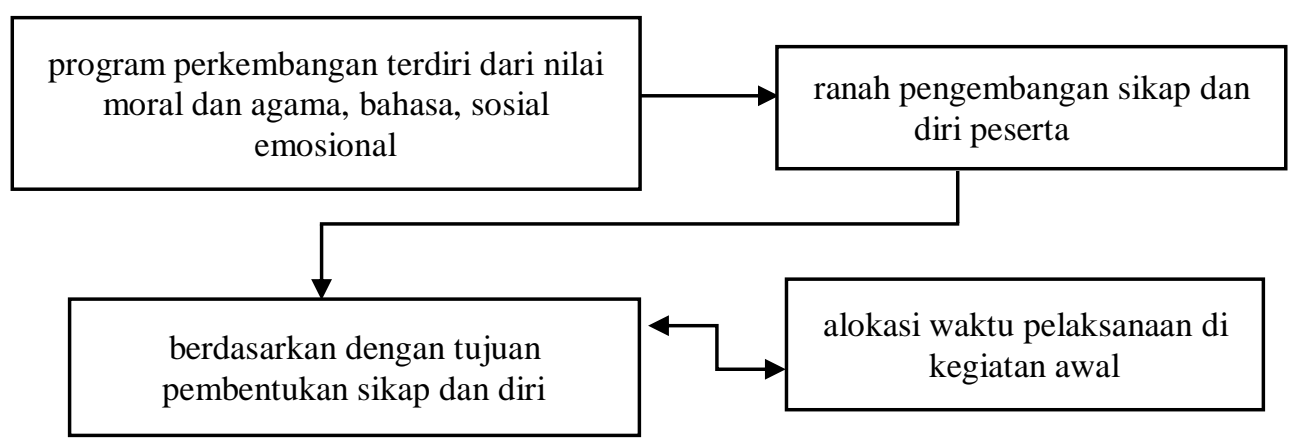

Gambar 1. Skema Rancangan Preparatory Peserta didik di Lingkungan PAUD

Aktivitas play stage dilakukan secara terus menerus oleh peserta didik melalui alat permainan edukatif (APE) dengan menjadikan guru sebagai role model. Rencana pelaksanaan pendampingan dengan kegunaan APE digunakan untuk merangsang keingintahuan, pemahaman peserta didik dengan melakukan proses meniru melalui setiap kegiatan. Peserta didik akan secara ilmiah belajar dengan mengikuti kegiatan awal, inti dan akhir. Kegiatan play stage dilakukan agar 
peserta didik mampu belajar, dengan cara membangun pengetahuannya melalui memperhatikan dan meniru kegiatan yang dicontohkan guru di PAUD. Kegiatan yang dilakukan antara lain peserta didik diminta untuk mewarnai buku gambar setelah diberikan contoh oleh guru pendamping dan peserta didik lain lakukan, sehingga berusaha untuk mencoba melakukan. Pendampingan oleh guru terhadap peserta didik juga terhadap semua kegiatan ketika berlatih cuci tangan, memperhatikan dan mencoba memegang pensil warna, mencoba makan dan minum sendiri, memakai sepatu sendiri, menirukan lagu yang dinyanyikan guru.

Tujuan kegiatan yang diberikan sebagai upaya agar peserta didik akan menempatkan dirinya dapat melakukan seperti yang dilakukan guru pendamping dan juga kawan sebayanya. Peserta didik diusia dini memiliki daya pengetahuan terhadap sesuatu hal yang baru. Selain itu juga ketika kawan sebayanya bisa melakukan, akan ada muncul keinginan untuk juga melakukan hal yang sama. Artinya ketika anak sebagai peserta didik sudah harus memiliki pemahaman sendiri dalam menirukan terhadap apa yang dilakukan oleh orang disekitarnya.

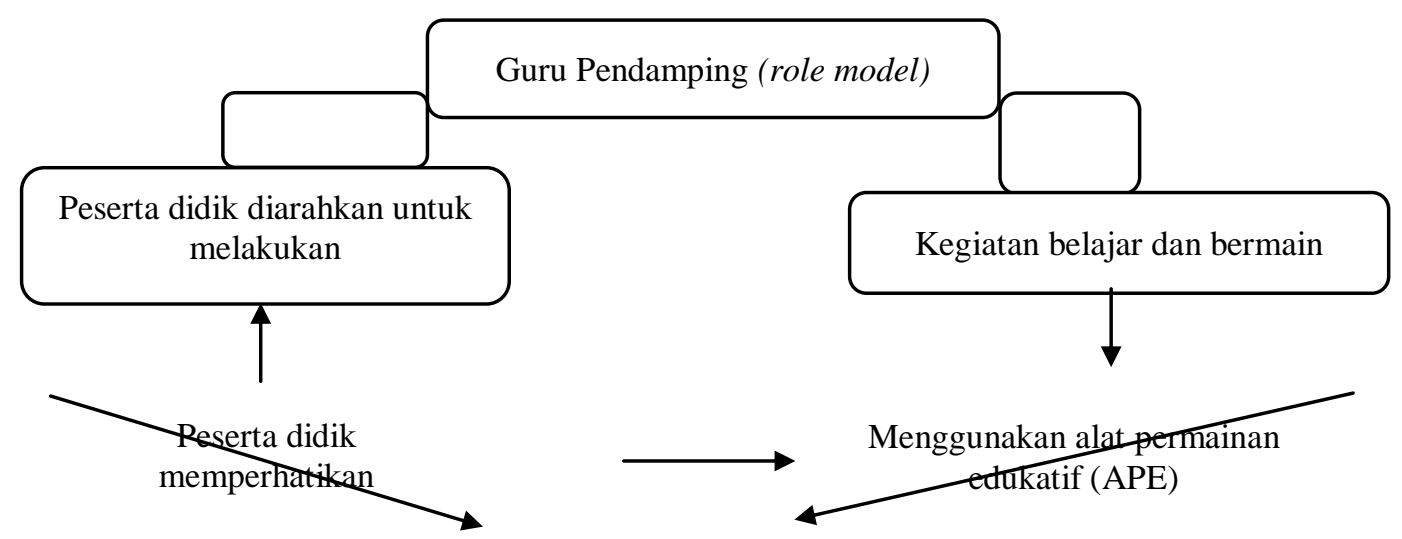

Gambar 2. Skema Mekanisme terjadinya Play Stage Peserta Didik

Kegiatan game stage peserta didik yang diartikan sebagai kesadaran yang sudah dimiliki untuk melaksanakan kegiatan secara otomatis dan sudah terbiasa dilakukan. Kemampuan dalam menempatkan diri secara melalui kegiatan bermain dan belajar dengan adaptasi di lingkungan PAUD. Selain untuk membentuk kesadaran diri melalui pemahaman terhadap aktivitas dan aturan yang harus dilakukan, kegiatan ini juga sebagai upaya mengefektifkan interaksi peserta didik dengan kawan sebaya dan orang dewasa. Guru pendamping hanya mengarahkan, 
mengawasi, dan menunggu sampai peserta didik itu siap belajar mandiri. Secara otomatis kemandirian diri dan kepercayaan diri peserta didik akan terbentuk pada setiap yang dilakukan. Rasa tanggung jawab juga terbentuk dalam dirinya, dengan kemampuan berpikir sendiri secara otomatis. terbentuknya tindakan kemandirian peserta didik terlihat pada aktivitas yang dilakukan, keberanian sebagai bagian dari kepercayaan diri dengan menyampaikan kepada guru pendamping seperti ingin ke toilet, ingin membuang sampah sendiri. Tindakan lain diperoleh dari sikap peserta didik yang membantu kawan ketika mengalami kesulitan dalam mengambil alat permainan. Melalui aktivitas yang diperoleh ini artinya melalui tindakan tersebut peserta didik sudah terbiasa dan nyaman dengan kegiatan di PAUD serta berinteraksi dengan kawan sebaya yang lain.

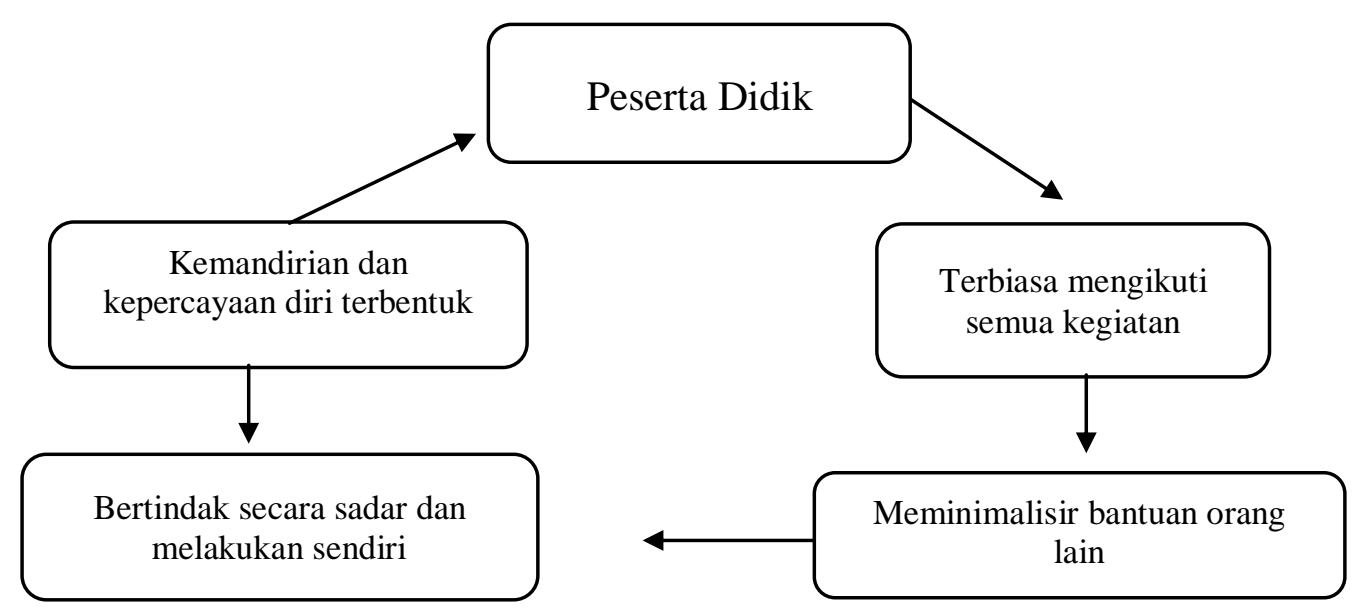

Gambar 3. Skema Mekanisme terbentuknya Game Stage Peserta Didik

Generalized stage peserta didik merupakan keseluruhan dari hasil proses sosialisasi yang telah dilakukan. Hasil yang akan terlihat berhasil atau tidak dalam pembentukan kemandirian dan kepercayaan diri peserta didik, ketika dalam kegiatan pembelajaran di PAUD dan cara menempatkan dirinya pada lingkungan sosial. Lebih luasnya peserta didik akan menunjukkan pembentukan karakter diri melalui interaksi yang melibatkan percakapan dan perilaku. Mengoptimalkan proses sosialisasi dengan tujuan agar peserta didik mampu membiasakan diri untuk terlepas dan melepaskan diri dalam hal ketergantungan terhadap oranglain. Hasil observasi yang dilakukan oleh peneliti, sebagian besar peserta didik sudah memperlihatkan karakter kemandirian dan kepercayaan diri, seperti ketika datang 
ke PAUD sudah bisa langsung mencium tangan guru dan melepaskan sepatu sendiri. Untuk kegiatan materi I dan II sudah bisa mengikuti dan mengerjakan materi yang diberikan pada hari tersebut. Selanjutnya juga terlihat pada kegiatan istirahat dengan langsung mencuci tangan sendiri sebelum makan bekal. Tetapi, ada beberapa kegiatan yang masih belum bisa dilakukan peserta didik seperti pergi ke toilet sendiri, dan ada sebagian kecil peserta didik yang masih belum memiliki karakter kemandirian dan kepercayaan diri. Tenaga pendidik PAUD sebagai mentor (pendamping) yang sifatnya persuasif kepada peserta didik dalam proses sosialisasi pembentukan karakter kemandirian dan kepercayaan diri membutuhkan kerjasama dengan orangtua melalui komunikasi rutin untuk mengoptimalkan kemampuan diri peserta didik.

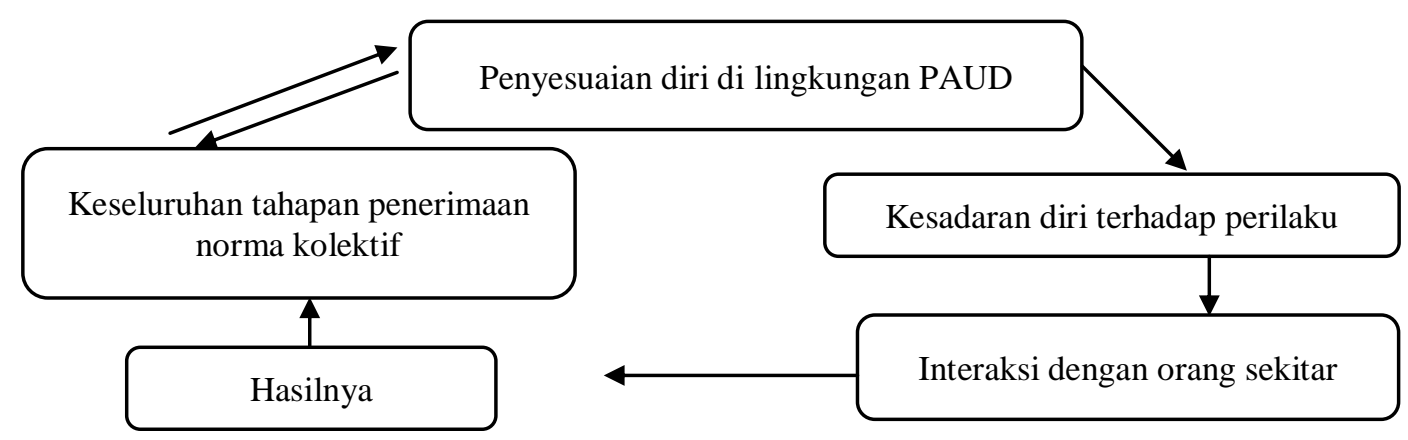

Gambar 4. Skema Mekanisme Generalized Stage Peserta Didik

\section{Hambatan Proses Sosialisasi Pembentukan Kemandirian dan Kepercayaan Diri Peserta Didik}

Hambatan yang terdapat dalam proses sosialisasi yang dilakukan pada lingkungan PAUD yaitu masih minimnya kemampuan persiapan diri (preparatory) ketika berada dalam fase adaptasi peserta didik. Penyesuaian diri dengan lingkungan dan aktivitas baru merupakan fase dimana peserta didik didik untuk memiliki kemauan mengikuti kegiatan. Kemampuan diri peserta didik yang masih minim diperoleh dari hasil pendidikan pertama yang diterima dalam lingkungan informal yaitu pola asuh orang tua dan keluarga. Hasil tersebut berdampak pada gambaran kemampuan diri peserta didik ketika mengikuti proses persiapan (preparatory) yang dilakukan guru PAUD. Kekurangan yang dimiliki itu 
memberikan dampak pada kemampuan diri peserta didik dalam mengikuti kegiatan ataupun pemahaman orang lain terhadap yang disampaikan.

Keterbatasan fasilitas PAUD yang juga berdampak pada kurang maksimalnya proses kegiatan pembelajaran dalam upaya membentuk kemandirian dan kepercayaan diri peserta didik. Minimnya fasilitas PAUD diperoleh dari keterbatasan lingkungan pendidikan yang terdiri dari satu ruangan kelas untuk semua usia peserta didik, hanya terdiri dari satu ruangan kelas, yang dimana semua aktivitas dari belajar, bermain, makan, dilakukan hanya dalam satu ruangan. toilet yang sama untuk guru PAUD dengan tidak ada pembedanya antara untuk laki-laki dan perempuan, alat permainan luar ruangan yang masih kurang dengan tingkat keamanan yang masih harus diperbaiki. Selain itu fasilitas Untuk alat permainan edukatif di dalam ruangan yang digunakan relatif sama setiap hari yang seharusnya lebih lengkap untuk mendukung terbentuknya karakter kemandirian dan kepercayaan diri.

Keterbatasan tenaga pendidik di lingkungan PAUD yang hanya terdiri dari guru yang berjumlah dua orang dengan berstatus tenaga honorer. Latar belakang pendidikan yaitu sekolah pendidikan guru (SPG) dan S1 AUD. Sehingga memberikan gambaran pada kemampuan guru pendamping dalam proses kegiatan melalui hasil kinerja mencakup aspek professional, sosial dan secara personal. Faktanya tergambar pada keadaan di PAUD, dimana guru pendamping hanya memberikan materi pembelajaran edukasi berdasarkan alat permainan edukatif (APE) yang tersedia sehingga hasilnya berdampak pada kualitas kompetensi guru tersebut.

\section{Strategi yang Digunakan untuk Mengatasi Hambatan Proses Sosialisasi Pembentukan Kemandirian dan Kepercayaan Diri Peserta Didik}

Melalui pelaksanaan sosialisasi pembentukan kemandirian dan kepercayaan diri pada peserta didik PAUD Bina Ananda yang termasuk pada satuan pendidikan nonformal. Agar pihak PAUD dapat memperbaiki kualitas pelayanan pendidikan dan untuk meningkatkan kualitas sumber daya manusia dalam pendidikan terutama 
anak usia dini yaitu melalui strategi yang dapat digunakan untuk mengatasi hambatan yang ada.

Optimalisasi kemampuan diri peserta didik dengan kegiatan pembelajaran menggunakan alat permainan edukatif (APE) untuk meningkatkan kemampuan kognitif, bahasa dan sosial emosional. Hal ini dikarenakan banyak kekurangan terhadap pemenuhan kemampuan diri peserta didik seperti yang diperoleh terhadap kegiatan di PAUD. Anak yang sebelumnya hanya menerima pendidikan melalui lingkungan keluarga atau informal dari orangtua dan orang dewasa disekitar, serta menerima pemahaman dan persiapan diri yang belum maksimal dengan melihat pada latarbelakang hasil gambaran preparatory stage peserta didik. Guru sebagai entor (pendamping) yang sifatnya persuasif kepada peserta didik dalam proses sosialisasi pembentukan karakter kemandirian dan kepercayaan diri, sehingga dibutuhkan kerjasama dengan orangtua melalui komunikasi rutin untuk mengoptimalkan kemampuan diri peserta didik.

Pemenuhan fasilitas untuk menunjang keberhasilan proses sosialisasi dan juga sebagai outcome PAUD dari orangtua peserta didik. Pengadaan pendidikan nonformal untuk peserta didik harus memenuhi standar dan persyaratan pengadaan PAUD menurut Permendiknas Nomor 58 Tahun 2019 yaitu kebutuhan jumlah ruangan dan luas disesuaikan jenis layanan, jumlah anak dan kelompok usia. Ruangan yang harus dimiliki oleh pihak PAUD terdiri dari ruang dalam dan ruang luar, kamar mandi, toilet, air bersih yang cukup dan bersih. Memiliki sarana yang harus disesuaikan dengan usia,dan jumlah anak, serta fasilitas permainan yang dapat mengembangkan berbagai konsep diri peserta didik.

\section{SIMPULAN}

Proses sosialisasi pembentukan kemandirian dan kepercayaan diri peserta didik PAUD dapat dilakukan melalui aktivitas bermain dengan menggunakan alat permainan edukatif (APE). Aktivitas yang diikuti peserta didik di PAUD; pertama diperoleh bahwa proses preparatory sebagai tahapan terpenting dalam melakukan penyesuaian diri dan pengenalan terhadap lingkungan belajar, sehingga menjadi penentu peserta didik untuk mampu menirukan (play stage) aktivitas yang 
dicontohkan oleh guru. Melalui aktivitas yang dilakukan secara terus menerus, akan menjadi suatu kebiasan diri dengan mampu bertindak (game stage) secara mandiri, sehingga pada proses penerimaan norma kolektif (generalized) akan sangat terlihat melalui interaksi dengan lingkungan sosial masyarakat. Kedua, selama proses sosialisasi dilakukan diperoleh hambatan yang ditemukan yaitu kemampuan diri peserta didik yang ternyata kurang maksimal pada proses preparatory dalam pengenalan lingkungan dan aktivitas PAUD. Selain itu keterbatasan fasilitas dan kurangnya tenaga pendidik PAUD menjadi hambatan dalam proses sosialisasi.

Secara keseluruhan untuk memperbaiki setiap proses dan mengatasi hambatan dalam kegiatan PAUD, terdapat strategi yang digunakan untuk dijadikan solusi sebagai berikut; mengoptimalkan kemampuan diri peserta didik dengan menjalin komunikasi terhadap orangtua peserta didik agar juga mendukung pendidikan lanjutan melalui kegiatan dirumah, pemenuhan fasilitas oleh pihak PAUD disesuaikan Permendiknas Nomor 58 Tahun 2019 dan peningkatan kompetensi guru PAUD agar berdampak pada outcome PAUD.

\section{DAFTAR PUSTAKA}

Abdul, Majid, and Andayani Dian. (2017). "Pendidikan Agama Islam Berbasis Kompetensi Konsep Dan Implementasi Kurikulum 2004.” P. 109 in, edited by wardan S anang. Bandung: PT Remaja Rosdakarya.

Arikunto Suharsimi. (2013). Dasar-Dasar Evaluasi Pendidikan. kedua. jakarta: bumi aksara.

Dariyo Agus. (2011). Psikologi Perkembangan Anak Tiga Tahun Pertama. kedua. jakarta: Refika Aditama.

Denzin K. Norman, and yvonna S. Lincoln. (2009). "Handbook Of Qualitative Research.” Pp. 256-58 in, edited by Qudsy Z Saifuddin. Yogyakarta: Belajar Pustaka.

Idi Abdullah. (2014). Sosiologi Pendidikan (Individu, Masyarakat, Dan Pendidikan). keempat. edited by safarina. jakarta: PT RajaGrafindo Indoenesia.

Imas, Kurniasih, and Sani Berlin. 2017. "Pendidikan Karakter (Internalisasi Dan Metode Pembelajaran Di Sekolah).” P. 7 in, edited by J. Adi. jakarta: distribusi solusi.

Koro, Maxsel, Ery Tri Djamika, and M. Ramli. (2017). "Self-Regulated Learning Sebagai Strategi." (1997):788-95. 
Lickona Thomas. 2(013). Character Matters (Persoalaan Karakter). pertama. edited by W. Uyu and Suryani. jakarta: bumi aksara.

Masrun, Martono, Haryanto, Purba Harjito, and Muhana Sofiati. (1986). "Studi Mengenai Kemandirian Pada Penduduk Di Tiga Suku Bangsa (Jawa, Batak, Bugis)." 86.

Muchlas, Samani, and haryanto. (2017). "Pendidikan Karakter (Konsep Dan Model).” P. 2 in, edited by K. Adriyani. Bandung: PT Remaja Rosdakarya.

Mustofa Bisri. (2016). Dasar-Dasar Pendidikan Anak Pra Sekolah. pertama. Yogyakarta: dua satria offset.

Novan, Wiyani A., and barnawi. (2017). "Format PAUD (Konsep, Karakteristik Dan Implementasi Pendidikan Anak Usia Dini).” P. 25 in, edited by Sandra Meita. Jogjakarta: Ar-ruzz media.

Ritzer George. (2012). Teori Sosiologi- Dari Sosiologi Klasik Sampai Perkembangan Terakhir Postmodern. kedelapan. edited by djohar a winda. Yogyakarta: pustaka belajar.

Rozana, Asiatik Afrik, Abdul Hamid Wahid, and Chusnul Muali. (2017). "Smart Parenting Demokratis Dalam Membangun Karakter Anak." Jurnal Pendidikan Anak 4(1):1-16.

Sunarto, Kamanto. (2004). Pengantar Sosiologi. kedua. edited by K. Sunarto. jakarta: Lembaga Penerbit Fakultas Ekonomi Universitas Indonesia. 